\title{
Seasonal dynamics of soil respiration and nitrification in three subtropical plantations in southern China
}

\author{
Weixia Wang ${ }^{(1-2)}$, Ruimei \\ Cheng ${ }^{(2-3)}$, Zuomin Shi ${ }^{(2-3)}$, \\ Joachim Ingwersen ${ }^{(4)}$, Da Luo ${ }^{(2)}$, \\ Shirong Liu ${ }^{(2)}$
}

\begin{abstract}
Numerous studies have documented that soil respiration and nitrogen cycling show a distinct seasonal dependence regulated by environmental factors (e.g., soil temperature and soil water content). The mechanisms controlling the seasonal dependence of these two key ecosystem processes have rarely been linked to both soil microbial community and soil environmental factors. Here, we present results on the seasonal patterns of soil respiration and gross nitrification rates in three subtropical plantations of Pinus massoniana, Castanopsis hystrix and Erythrophleum fordii over a period of 11 months. Turnover rates were measured with the Barometric Process Separation technique (BaPS). We elucidated how soil respiration and gross nitrification are controlled by the soil microbial community and by soil environmental factors. Soil respiration and gross nitrification showed strong seasonal dynamics, although no significant differences were observed among plantations. The turnover rates were the highest during the wet season and the lowest during the dry season. Microbial biomass, total phospholipid fatty acids (PLFAs), fungal PLFAs and bacterial PLFAs peaked during the dry season. Both soil respiration and gross nitrification rates were positively correlated with soil temperature and soil water content. Microbial biomass decreased with increasing turnover rates. Our findings highlight that carbon and nitrogen turnover rates were mostly controlled by soil temperature and soil water content.
\end{abstract}

Keywords: Soil Respiration, Nitrification, PLFA, Soil Microbial Community, Nfixing Tree Species, Subtropical China

2005, Luan et al. 2012).

The $\mathrm{N}$ cycle in forests is a complex system with close linkages and interactions between soil, plants and microbes. The natural $\mathrm{N}$ supply for plants and microorganisms is derived from the mineralization of organic N compounds (Das et al. 1997). This process occurs in two steps, ammonification and nitrification, which play a key role by making inorganic $\mathrm{N}$ compounds available for plants and microbes. The process is influenced by a number of factors such as composition and diversity of the soil microbial community, substrate quality and quantity, and environmental conditions organic C) are the main factors controlling heterotrophic respiration (Ryan \& Law soil respiration (Janssens et al. 2001), whereas the soil biophysical environment and substrate availability (e.g., aboveground and belowground litter fall, soil

(1) College of Forestry and Horticulture, Xinjiang Agricultural University, Urumqi 830052 (China); (2) Key Laboratory on Forest Ecology and Environmental Sciences of State Forestry Administration; Institute of Forest Ecology, Environment and Protection, Chinese Academy of Forestry, Beijing 100091 (China); (3) Co-Innovation Center for Sustainable Forestry in Southern China, Nanjing Forestry University, Nanjing 210037 (China); (4) Institute of Soil Science and Land Evaluation, University of Hohenheim, Stuttgart D-70593 (Germany)

\section{@ Shi Zuomin (shizm@caf.ac.cn)}

Received: Aug 28, 2015 - Accepted: Feb 02, 2016

Citation: Wang W, Cheng R, Shi Z, Ingwersen J, Luo D, Liu S (2016). Seasonal dynamics of soil respiration and nitrification in three subtropical plantations in southern China. iForest 9: 813-821. - doi: 10.3832/ifor1828-009 [online 2016-05-29]

Communicated by: Elena Paoletti (temperature and water content - Templer et al. 2003, Grenon et al. 2004). These factors are influenced by tree species and plantations. In fact, tree species are known to affect the physicochemical and biological characteristics of soils (Binkley \& Giardina 1998, Staelens et al. 2012). Soil microbial biomass (MB), activity, and community structure might thus be tree species dependent (Hackl et al. 2005). Tree species also differ in the quality of leaf litter (e.g., $\mathrm{C} / \mathrm{N})$, which directly influences the quality and quantity of organic matter input (Templer et al. 2003, Brüggemann et al. 2005). Moreover, root litter is also species dependent and directly affects root exudation (Burton et al. 2007). Accordingly, microbes receive organic matter of varying quality from different tree species (Templer et al. 2003). This, in turn, may lead to changes in soil microbial communities and MB (Bauhus et al. 1998), which subsequently influence soil $\mathrm{N}$ transformations (Patra et al. 2006, Ste-Marie \& Houle 2006). Most studies on microbial $\mathrm{N}$ cycling have concentrated on determining net nitrification rates (Munson \& Timmer 1995, Paavolainen \& Smolander 1998, Westbrook et al. 2006) rather than gross rates. Direct comparisons of net and gross nitrification rates, how ever, reveal that the former can be one order of magnitude lower than the latter. Thus changes in the $\mathrm{NO}_{3}$ pool do not necessarily reflect the total turnover from $\mathrm{NH}_{4}{ }^{+}$ 
to $\mathrm{NO}_{3}{ }^{-}$(Stark \& Hart 1997, Neill et al. 1999, Ingwersen et al. 1999). These findings highlight the importance of measuring gross nitrification rates to understand $\mathrm{N}$ transformation in forest ecosystems.

Only few studies have investigated gross nitrification in soil under different tree species/forest types. Brüggemann et al. (2005) studied soil respiration, gross $\mathrm{N}$ mineralization and gross nitrification in pure stands of different temperate tree species. Matejek et al. (2010) and Rosenkranz et al. (2010) investigated ammonification and gross nitrification in forest soil layers in southern Germany (temperate climate). Comparable comprehensive studies are missing for subtropical climate regions.

Southern China, which is located mostly in the subtropical region, has 25 million hectares of plantations (Wang et al. 2010a). Plantations are becoming a key component of the world's forest resources and play an important role in the context of sustainable forest management (Wang et al. 2010b). This calls for studies on soil $\mathrm{C}$ and $\mathrm{N}$ transformation under the main tree species used for afforestation to better understand the $\mathrm{C}$ and $\mathrm{N}$ cycle of subtropical plantation ecosystems.

Accordingly, the objective of this study was to determine the seasonal dynamics of soil respiration and nitrification in the top soil layer in subtropical plantations and to elucidate the relationships of these two key turnover processes with the composition of the soil microbial community (bacteria vs. fungi) and the two environmental factors soil temperature and soil water content.

\section{Materials and methods}

\section{Study area}

The study was conducted at the Experimental Center of Tropical Forestry, the Chinese Academy of Forestry $\left(22^{\circ} 06^{\prime} \mathrm{N}, 106^{\circ}\right.$ $46^{\prime}$ E), Pingxiang City, Guangxi Zhuang Autonomous Region, China. Annual rainfall is about $1400 \mathrm{~mm}$ and occurs primarily from April to September. The annual mean temperature is $21{ }^{\circ} \mathrm{C}$, the mean monthly minimum is $12.1^{\circ} \mathrm{C}$, and the mean monthly maximum is $26.3^{\circ} \mathrm{C}$. The soil was formed on granite, classified as red soil in Chinese soil classification, equivalent to Oxisol in USDA Soil Taxonomy (Liang \& Wen 1992, Wang et al. 2010a, Huang et al. 2014).

We studied three of the most dominant plantations: one conifer plantation (Pinus massoniana Lamb.) and two broadleaved plantations (Castanopsis hystrix Miq. and Erythrophleum fordii Oliv.). E. fordii is a $\mathrm{N}$ fixing species. These monoculture plantations were selected based on their similar topography, soil texture, stand age and management history. The three plantations were established after a clear-cut harvest of $P$. massoniana plantation in 1978, at an elevation of $350 \mathrm{~m}$, over areas ranging from 2.2 to 4.8 hectares. Stem density varied from 410 to 415 trees per hectare, the diameter at breast height (DBH) ranged from 22.4 to $26.4 \mathrm{~cm}$. In each plantation, five sampling squared plots $(20 \times 20 m)$ were randomly selected and delineated.

\section{Soil sampling}

Soil was sampled monthly over a period of 11 months (from August 2011 to July 2012; except January, the date of sampling was the same every month, i.e., $15^{\text {th }}$ ), covering the entire season, i.e., wet, dry and intermediate conditions. Five intact soil cores were randomly taken from the top soil layer using a soil corer $(5.6 \mathrm{~cm}$ diameter, $4.1 \mathrm{~cm}$ height) at each plot after removing the litter (Kiese et al. 2008, Wang et al. 2010b, Wang et al. 2013). The intact soil cores were analyzed for gross nitrification and soil respiration rates using the BaPS technique (UMS GmbH Inc., Germany - Ingwersen et al. 1999, Breuer et al. 2002, Kiese et al. 2002).

Bulk soil samples for chemical analysis were collected from the top soil layer (0-5 $\mathrm{cm}$ ) in late February 2012 (dry season) and July 2012 (wet season). A total of six soil cores per plot were randomly collected using a 5.0-cm-diameter stainless steel core and bulked to one composite sample. After collection, samples were immediately delivered to the laboratory for further analysis. In the lab, each composite sample was passed through a sieve ( $2 \mathrm{~mm}$ mesh size), and plant material was manually removed from the sieved soil. The sieved soil was divided into three subsamples. The first subsample was used to determine soil organic carbon (SOC), total nitrogen (TN) and soil $\mathrm{pH}$. The second subsample was kept at $4{ }^{\circ} \mathrm{C}$ for analysis of nitrate $\left(\mathrm{NO}_{3}-\mathrm{N}\right)$, ammonium $\left(\mathrm{NH}_{4}^{+}-\mathrm{N}\right)$, microbial biomass carbon (MBC) and microbial biomass nitrogen (MBN). The third subsample was used for total PLFAs, fungal and bacterial PLFAs determinations, and was stored at $-20^{\circ} \mathrm{C}$.

\section{Physicochemical analyses}

Soil samples collected for physicochemical analyses were ground to pass through a $0.25 \mathrm{~mm}$ sieve. SOC was measured using the potassium dichromate vitriol oxidation method (Liu et al. 1996) and TN concentration was measured after semimicro-Kjeldahl digestion using a flow injection autoanalyzer (FIA ${ }^{\oplus}$, Lachat Instruments, USA). Soil $\mathrm{C} / \mathrm{N}$ values were calculated as the ratio of SOC to TN. Soil pH was determined using a 1:2.5 soil/water suspension. Inorganic N (ammonium and nitrate) was extracted with $2 \mathrm{M} \mathrm{KCl}$ solution. Ammonium and nitrate in extract were measured using the above flow injection auto-analyzer. Soil $M B C$ and $M B N$ were determined using the fumigation-extraction method (Vance et al. 1987, Tate et al. 1988). Specifically, soil samples from each experimental site were divided into paired subsamples of $20 \mathrm{~g}$. One subsample was immediately extracted with $60 \mathrm{ml} 0.5 \mathrm{M} \mathrm{K}_{2} \mathrm{SO}_{4}$. The second subsample was fumigated with chloroform vapor for $48 \mathrm{~h}$ in a desiccator followed by
10 vacuum/purge cycles, and then extracted as described above. Soil extractable organic $\mathrm{C}$ and $\mathrm{TN}$ in the $\mathrm{K}_{2} \mathrm{SO}_{4}$ extracts before and after the fumigation were quantified using a total $\mathrm{C} / \mathrm{N}$ analyzer (Multi-N/C $2100^{\oplus}$, Analytik Jena AG, Germany). The released $C$ and $N$ were converted to $M B C$ and $M B N$, respectively, using the conversion factors $\mathrm{K}_{\mathrm{ec}}=0.45$ and $\mathrm{K}_{\mathrm{en}}=0.45$. Soil temperatures at $5 \mathrm{~cm}$ depth $\left(T_{5}\right)$ were determined by a digital thermometer concomitantly with the soil samplings. All results were expressed per unit of oven-dried soil weight.

\section{Phospholipid fatty acid extraction}

The soil microbial community was characterized using PLFA analysis as described by Bossio \& Scow (1998). Lipids were extracted from $8 \mathrm{~g}$ of dry-weight-equivalent fresh soil with a one-phase mixture of chloroform, methanol and phosphate buffer (1:2:0.8). The separated fatty acid methylesters were re-dissolved in $200 \mu \mathrm{l}$ hexane containing 19:0 as an internal standard and were analyzed using a Hewlett-Packard 6890 Gas Chromatograph equipped with an Ultra 2-methyl polysiloxane column. Concentrations of each PLFA were calculated based on the 19:0 internal standard concentrations. The abundance of individual fatty acids was determined as nmol per $g$ of dry soil and standard nomenclature was used (Tunlid et al. 1989).

Bacteria were considered to be represented by 12 PLFAs (i14:0, i15:0, a15:0, 15:0,

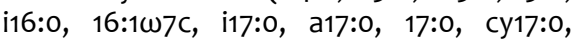

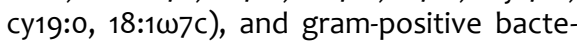
ria were identified by the PLFAs i14:0, i15:0, a15:0, i16:0, i17:0, a17:0, gram-negative bac-

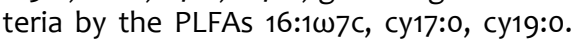
The fungi were considered to be represented by the PLFAs $18: 2 \omega 6.9 \mathrm{C}$ and $18: 1 \omega 9 \mathrm{C}$ (Bååth \& Anderson 2003, Högberg et al. 2007). A ratio of the gram-positive bacteria to the gram-negative bacteria PLFAs $\left(\mathrm{G}^{+} / \mathrm{C}^{-}\right)$ was used as an indicator of changes in the relative abundance of these two microbial groups; the ratio of $18: 2 \omega 6.9 \mathrm{C}$ and $18: 1 \omega 9 \mathrm{C}$ to total bacterial PLFAs was used to estimate the ratio of fungal to bacterial biomass (F/B) in soils (Bardgett \& Hobbs 1996). Several other PLFAs such as 16:0, 16:1 2OH, 16:1 $\omega_{5 \mathrm{C}} \mathrm{C}, 10 \mathrm{Me} 16: 0$ and 10Me17:0 were detected and also used to analyze the composition of microbial community.

\section{Determination of gross nitrification and soil respiration}

The BaPS technique enables simultaneous determination of gross nitrification and soil respiration (Ingwersen et al. 1999, 2008). Previous studies testing the BaPS method against the ${ }^{15} \mathrm{~N}$ pool dilution technique revealed that using the default value of the respiration quotient (RQ) of unity tends to overestimate gross nitrification rates (Müller et al. 2004, Rosenkranz et al. 2006). Müller et al. (2004) thus suggested using the ${ }^{15} \mathrm{~N}$ pool dilution technique for determining the $\mathrm{RQ}$ value needed in the BaPS 
method. For acid forest soils, Rosenkranz et al. (2006) and Matejek et al. (2008) found average RQ values of $0.90 \pm 0.01$ and $0.89 \pm 0.02$, respectively. We therefore used a RQ of 0.9 in the present study. The autotrophic-to-heterotrophic nitrification ratio was kept at the default ratio of 3:1 (Ingwersen et al. 1999, 2008).

Gross nitrification and soil respiration rates were determined by incubating intact soil cores ( $5.6 \mathrm{~cm}$ diameter, $4.1 \mathrm{~cm}$ height), which were taken from the top soil from each sampling spot. Five replicates per experimental plantation were taken at each sampling date. Immediately after sampling, the undisturbed soil cores were sealed with parafilm and transported to the laboratory, where they were stored in the dark at in situ soil temperature as determined by use of Pt10o probes at the field site at 2 $\mathrm{pm}$. Soil samples were incubated in the BaPS incubation chamber for $24 \mathrm{~h}$ at stable in situ soil temperatures. At the end of the incubation, soil water content and bulk density were determined gravimetrically by drying soil samples at $105^{\circ} \mathrm{C}$ for $24 \mathrm{~h}$. Waterfilled pore space (WFPS) was calculated using the following formula (Torbert \& Wood 1992 - eqn. 1):

$$
W F P S=\frac{S W C}{1-\frac{B D}{P D}}
$$

where $S W C$ is the volumetric water content $\left(\mathrm{cm}^{3} \mathrm{~cm}^{-3}\right), B D$ is the soil bulk density $\left(\mathrm{g} \mathrm{cm}^{-3}\right)$, and $P D$ denotes the soil particle density, which was assumed to be $2.65 \mathrm{~g}$ $\mathrm{cm}^{-3}$ (Torbert \& Wood 1992, Breuer et al. 2002).

\section{Statistical analysis and data evaluation}

Statistical analyses to determine significant differences between plantations and sampling dates were performed using SPSS $^{\circledast} 16.0$ and SigmaPlot ${ }^{\circledast} 10.0$ (SPSS Inc., Chicago, USA). To test for normal distribution of data we used the normal probability plot. For the analyses of variance we used a one-way analysis of variance (ANOVA) with a least significant differences (LSD) post hoc test. Correlations between gross nitrification and soil respiration were also analyzed by bivariate linear regressions.

We used an exponential equation (Luan et al. 2011) to describe the response of the two turnover processes to temperature (eqn. 2):

$$
k(T)=a \cdot \exp (b T)
$$

where $k$ is the turnover rate of soil respiration or gross nitrification, $T$ is soil temperature measured at $5 \mathrm{~cm}$ depth, and $a$ and $b$ are regression coefficients. The temperature sensitivity $\left(Q_{10}\right)$ was calculated as (Luan et al. 2011 - eqn. 3):

$$
Q_{10}=\exp (10 \cdot b)
$$

The effect of WFPS on the two turnover processes was evaluated with a simple lin- ear regression (Luan 2010) as follows (eqn. 4):

$$
k(W F P S)=c W F P S+d
$$

where $c$ and $d$ are the slope and the intercept, respectively.

We incubated the soil samples under in situ conditions, i.e., for incubation we used the temperature and the WFPS measured at the field site. To disentangle the effect of differing temperature and WFPS between the sites from other factors such as vegetation type or soil physicochemical properties, the rates were normalized for each month to the mean temperature and mean WFPS used in the incubations (eqn. 5):

$$
k^{*}=k \cdot \exp [b(T-\bar{T})] \frac{c \overline{W F P S}+d}{c \overline{W F P S}+d}
$$

where $k$ is the measured rate, and $k^{*}$ denotes the normalized rate, $T$ and $\bar{T}$ are the site and mean temperature $(\mathrm{N}=3)$, respectively. The same notation was used for WFPS.

The composition of the soil microbial community was summarized using principal component analysis (PCA) on the 19 individual PLFAs (nmol g ${ }^{-1}$ dry soil) from the
PLFA analysis of soil samples after standardization for equal unit variance. To test for normal distribution of data we used the normal probability plot. Differences in individual soil PLFA among plantations and seasons were tested with one-way analysis of variances (ANOVA).

\section{Results}

\section{Soil carbon and nitrogen pools}

Soil properties including SOC and TN varied significantly among the plantations (Tab. 1). In particular, the TN content of the top soil in the plantation of the $\mathrm{N}$-fixing species $E$. fordii was substantially higher than in the other two plantations. SOC in the $E$. fordii plantation was significantly higher than that in P. massoniana, although it was not significantly different from $C$. hystrix. There were no significant seasonal differences of the topsoil TN content among the plantations, while the SOC difference between dry and wet seasons was significant in the E. fordii and the C. hystrix plantations.

Soil $\mathrm{C}$ to $\mathrm{N}$ ratios and nitrate concentrations varied significantly between the $\mathrm{N}$-fixing vs. the non- $\mathrm{N}$-fixing plantations $(P<$ $0.05)$. Soil ammonium concentrations were

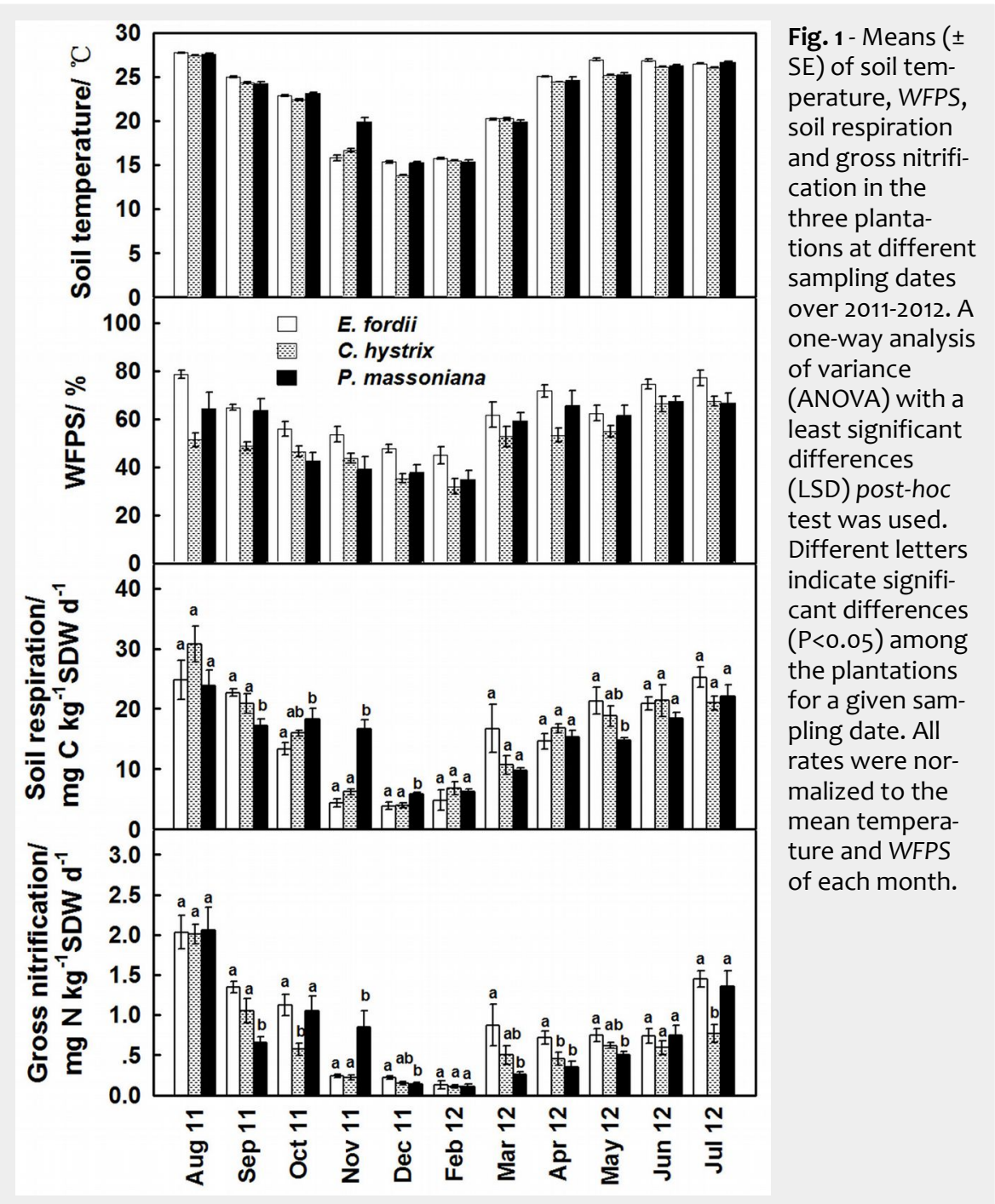


Tab. 1 - Soil $\mathrm{pH}$ and carbon and nitrogen pools of three subtropical plantations in Southern China. Data are means \pm standard error $(n=5)$. A one-way analysis of variance (ANOVA) with a least significant differences (LSD) post-hoc test was used. Different letters indicate significant differences $(\mathrm{P}<0.05)$ among plantations (lower case letters) or between different seasons (upper case letters).

\begin{tabular}{llccc}
\hline Variable & Season & $\begin{array}{c}\text { Erythrophleum } \\
\text { fordii }\end{array}$ & $\begin{array}{c}\text { Castanopsis } \\
\text { hystrix }\end{array}$ & $\begin{array}{c}\text { Pinus } \\
\text { massoniana }\end{array}$ \\
\hline pH & dry & $3.93 \pm 0.04 \mathrm{Aa}$ & $4.26 \pm 0.01 \mathrm{Ab}$ & $5.18 \pm 0.04 \mathrm{Ac}$ \\
& wet & $3.86 \pm 0.03 \mathrm{Aa}$ & $4.15 \pm 0.05 \mathrm{Bb}$ & $4.96 \pm 0.04 \mathrm{Bc}$ \\
SOC $\left(\mathrm{g} \mathrm{kg}^{-1}\right)$ & dry & $35.11 \pm 3.93 \mathrm{Aa}$ & $32.55 \pm 0.36 \mathrm{Aab}$ & $26.46 \pm 1.29 \mathrm{Ab}$ \\
& wet & $30.25 \pm 1.86 \mathrm{Ba}$ & $28.58 \pm 1.08 \mathrm{Ba}$ & $23.94 \pm 1.07 \mathrm{Ab}$ \\
$\mathrm{TN}(\mathrm{g} \mathrm{kg}-1)$ & dry & $2.86 \pm 0.31 \mathrm{Aa}$ & $2.11 \pm 0.14 \mathrm{Ab}$ & $1.59 \pm 0.09 \mathrm{Ab}$ \\
& wet & $2.50 \pm 0.13 \mathrm{Aa}$ & $2.03 \pm 0.20 \mathrm{Ab}$ & $1.60 \pm 0.04 \mathrm{Ab}$ \\
C: $\mathrm{N} \mathrm{ratio}^{\text {dry }}$ & dry & $12.28 \pm 0.34 \mathrm{Aa}$ & $15.63 \pm 1.05 \mathrm{Ab}$ & $16.69 \pm 0.16 \mathrm{Ab}$ \\
Nitrate $\left(\mathrm{mg} \mathrm{N} \mathrm{kg}^{-1}\right)$ & wet & $12.07 \pm 0.31 \mathrm{Aa}$ & $14.33 \pm 0.97 \mathrm{Ab}$ & $14.88 \pm 0.44 \mathrm{Bb}$ \\
& dry & $9.73 \pm 0.91 \mathrm{Aa}$ & $2.07 \pm 0.19 \mathrm{Ab}$ & $3.07 \pm 0.10 \mathrm{Ab}$ \\
Ammonium $\left(\mathrm{mg} \mathrm{N} \mathrm{kg}^{-1}\right)$ & wet & $7.54 \pm 0.15 \mathrm{Ba}$ & $3.30 \pm 0.19 \mathrm{Bb}$ & $2.91 \pm 0.20 \mathrm{Ab}$ \\
& dry & $18.26 \pm 1.71 \mathrm{Aa}$ & $17.26 \pm 1.68 \mathrm{Aab}$ & $13.38 \pm 0.83 \mathrm{Ab}$ \\
& wet & $18.83 \pm 0.61 \mathrm{Aa}$ & $16.28 \pm 1.21 \mathrm{Aa}$ & $15.74 \pm 1.38 \mathrm{Aa}$ \\
\hline
\end{tabular}

the highest in the $E$. fordii plantation, where the soil $\mathrm{pH}$ values were the lowest.

\section{Soil respiration rates}

Soil respiration rates were variable over the two seasons in all the plantations. The minimum respiration rates occurred during the dry season, when soil water content decreased to values below $45.0 \%$ WFPS. The maximum respiration rates were measured during the wet season when soil water content increased from $50.0 \%$ to
78.5\% WFPS (Fig. 1). Soil respiration rates were not significantly different among the plantations $(P>0.05)$. In the dry season, the rates were 3 -fold to 5 -fold lower than in the wet season (Fig. 1).

In all the three plantations, soil respiration increased with increasing temperature and WFPS (Fig. 2). The response to temperature was well described by the exponential function (eqn. 2). The coefficient of determination ranged from 0.76 to 0.86 (Fig. 2a). Based on the regression coefficient $b$ of eqn. 2, $Q_{10}$ values of respiration were $2.87,3.98$ and 2.70 in the E. fordii, $C$. hystrix and $P$. massoniana plantations, respectively. Moreover, we found a linear relation between soil respiration and WFPS $\left(R^{2}=0.31-0.56, P<0.0001-\right.$ Fig. $\left.2 b\right)$.

\section{Gross nitrification rates}

Gross nitrification rates showed a seasonal pattern similar to that of soil respiration (Fig. 1). The highest rates were recorded during the wet season and the lowest rates during the dry season. In the wet season, rates were up to 11-fold higher than in the dry season in the P. massoniana plantation (Fig. 1). Over the entire observation
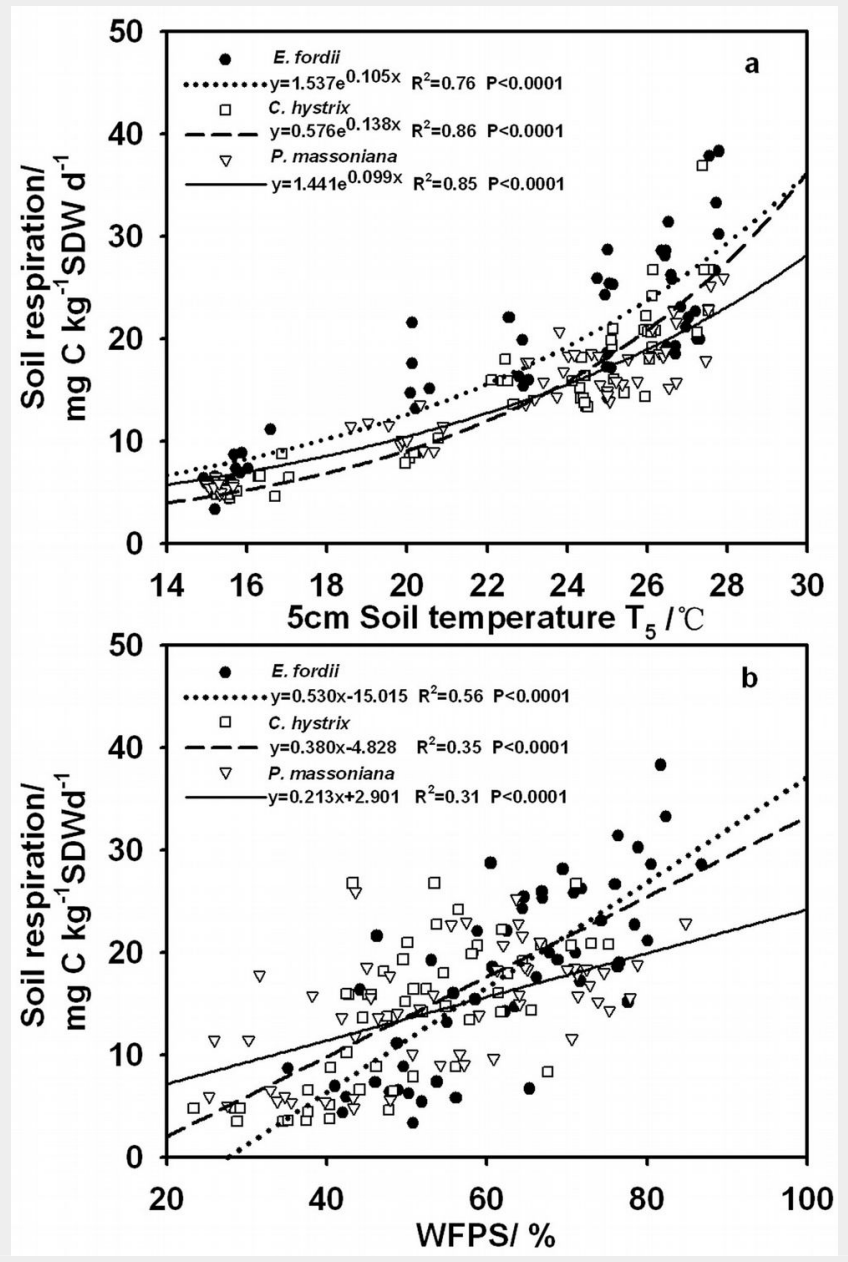

Fig. 2 - Relation between soil respiration rate and (a) soil temperature, or (b) water-filled pore space (WFPS) for the three plantations. Soil temperature was measured at $5 \mathrm{~cm}$ depth and soil water content was measured at 0-5 $\mathrm{cm}$ depth.
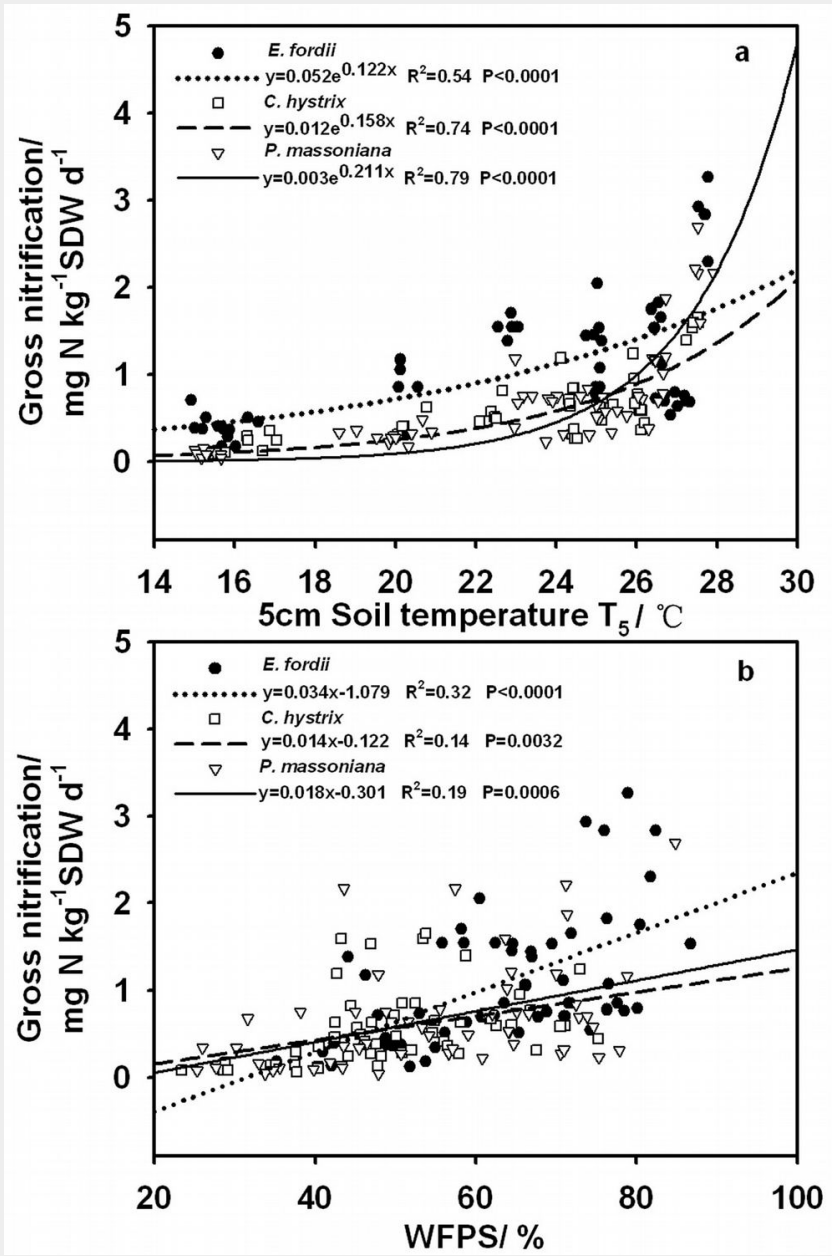

Fig. 3 - Relation between gross nitrification rate and (a) soil temperature, or (b) water-filled pore space (WFPS) for the three plantations. Soil temperature was measured at $5 \mathrm{~cm}$ depth and soil water content was measured at 0-5 cm depth. 
period, mean gross nitrification ranged between 0.11 and $2.06 \mathrm{mg} \mathrm{N} \mathrm{kg}^{-1}$ SDW d-1. The differences among the plantations were not significant (Fig. 1).

The response of gross nitrification to temperature was well described with the exponential approach ( $R^{2}$ between 0.54 and $0.79, P<0.0001$ - Fig. 3a). The data, however, scattered much more strongly around the fit compared with the soil respiration data. The calculated $Q_{10}$ values were 3.39, 4.85 and 8.25 for E. fordii, C. hystrix and $P$. massoniana, respectively. Gross nitrification showed a weak linear relationship to WFPS $\left(R^{2}=0.14-0.32, P<0.001\right.$ - Fig. 3b). Significant linear correlations between soil respiration and gross nitrification were found in all three plantations and the strongest correlation was in the E. fordii plantation (Fig. 4).

\section{Soil microbial community composition}

Total PLFAs did not differ among the plantations, while the abundance of individual PLFAs did (Tab. 2). In the wet season, the abundance of gram-positive bacteria (i15:0, a15:0, i16:0, i17:0, a17:0), gram-

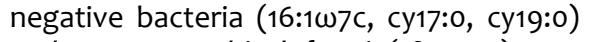
and ectomycorrhizal fungi (18:1w9c) was higher in the $C$. hystrix plantation than in the $E$. fordii plantation $(P<0.05)$. Saprophytic fungi (18:2w6.9C), arbuscular mycorrhizae fungi $\left(16: 1 \omega_{5} \mathrm{c}\right)$ and the ratio of $\mathrm{Gram}^{+}$to Gram differed significantly among the three plantations for two seasons; sa-

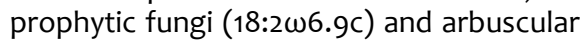
mycorrhizae fungi $\left(16: 1 \omega_{5} \mathrm{C}\right)$ were higher in

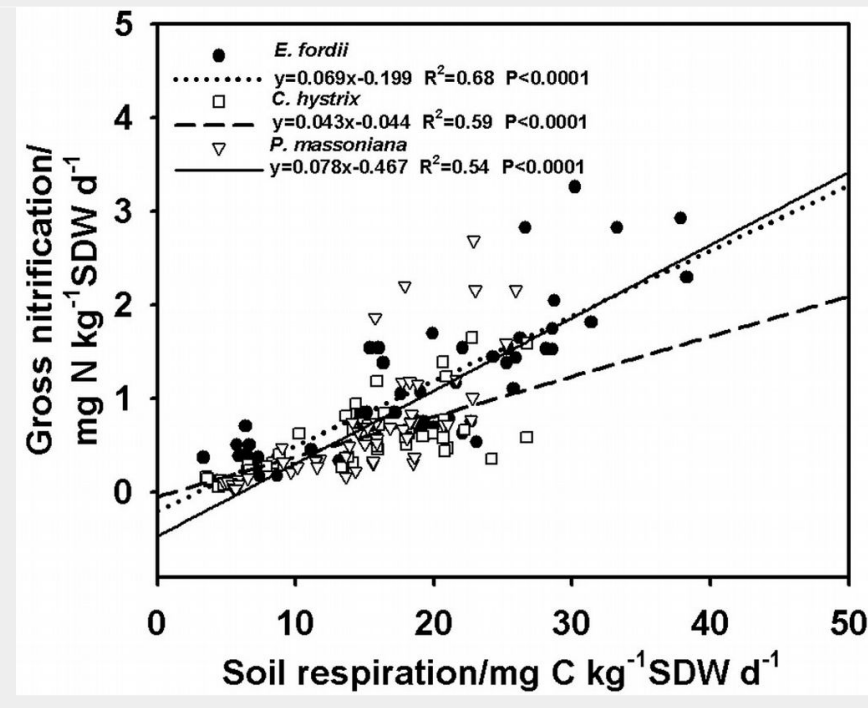

Fig. 4 - Linear correlation between gross nitrification rate and soil respiration rate for the three plantations.

the dry season for all the plantations (Tab. 2).

Principal Components Analysis of the microbial community composition, defined by the 19 PLFAs, showed that the first principal component (PC1) accounted for $65.8 \%$ and the second component (PC2) for $20.6 \%$ of the total variation in microbial communities (Fig. 5). The C. hystrix plantation was clearly separated from the other two on the PC1 axis (Fig. 5). This difference was mainly caused by the relatively higher abundances of Gram-positive bacteria, Gram-negative bacteria, saprophytic fungi and ectomycorrhizal fungi in the C. hystrix plantation. The E. fordii plantation was clearly separated from the P. massoniana plantation on the $\mathrm{PC} 2$ axis (Fig. 5) because the $E$. fordii plantation showed lower abundances of ectomycorrhizal fungi, arbuscular mycorrhizae fungi and Gram-negative bacteria (Tab. 2).

\section{Microbial community and its relation to} $C$ and $N$ turnover

Soil MB, total PLFAs, fungal PLFAs, bacterial PLFAs, soil respiration and gross nitrification rates were significantly different between the dry and wet season, while the latter two showed a seasonal pattern

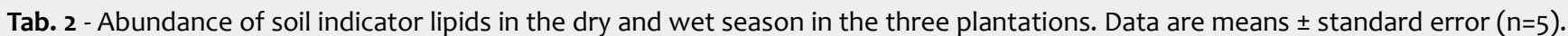
A one-way analysis of variance (ANOVA) with a least significant differences (LSD) post-hoc test was used. Different letters indicate significant differences $(\mathrm{P}<0.05)$ among plantations (lower case letters) or between different seasons (upper case letters).

\begin{tabular}{|c|c|c|c|c|c|}
\hline Group & $\begin{array}{l}\text { Lipid abundance } \\
\left(\mathrm{nmol} \mathrm{g}^{-1}\right)\end{array}$ & Season & $\begin{array}{l}\text { Erythrophleum } \\
\text { fordii }\end{array}$ & $\begin{array}{c}\text { Castanopsis } \\
\text { hystrix }\end{array}$ & $\begin{array}{c}\text { Pinus } \\
\text { massoniana }\end{array}$ \\
\hline \multirow[t]{2}{*}{ Overall } & Total PLFA & dry & $18.46 \pm 2.23 \mathrm{Aa}$ & $20.89 \pm 1.65 \mathrm{Aa}$ & $16.19 \pm 0.42 \mathrm{Aa}$ \\
\hline & & wet & $10.65 \pm 0.20 \mathrm{Ba}$ & $14.41 \pm 0.92 \mathrm{Bb}$ & $9.73 \pm 0.44 \mathrm{Ba}$ \\
\hline \multirow[t]{12}{*}{$\mathrm{Gram}^{+}$} & i14:0 & dry & $0.09 \pm 0.02 \mathrm{Aa}$ & $0.15 \pm 0.02 \mathrm{Ab}$ & $0.12 \pm 0.02 \mathrm{Aab}$ \\
\hline & & wet & $0.10 \pm 0.00 \mathrm{Aa}$ & $0.13 \pm 0.01 \mathrm{Aa}$ & $0.12 \pm 0.01 \mathrm{Aa}$ \\
\hline & i15:0 & dry & $2.16 \pm 0.37 \mathrm{Aa}$ & $3.32 \pm 0.36 \mathrm{Ab}$ & $2.27 \pm 0.21 \mathrm{Aa}$ \\
\hline & & wet & $1.12 \pm 0.06 \mathrm{Ba}$ & $1.88 \pm 0.19 \mathrm{Bb}$ & $1.45 \pm 0.12 \mathrm{Ba}$ \\
\hline & a15:0 & dry & $0.63 \pm 0.10 \mathrm{Aa}$ & $1.12 \pm 0.12 \mathrm{Ab}$ & $1.25 \pm 0.14 \mathrm{Ab}$ \\
\hline & & wet & $0.39 \pm 0.01 \mathrm{Ba}$ & $0.75 \pm 0.06 \mathrm{Bb}$ & $0.81 \pm 0.07 \mathrm{Bb}$ \\
\hline & i16:0 & dry & $1.89 \pm 0.35 \mathrm{Aab}$ & $1.92 \pm 0.11 \mathrm{Aa}$ & $1.16 \pm 0.05 \mathrm{Ab}$ \\
\hline & & wet & $1.19 \pm 0.06 \mathrm{Ba}$ & $1.51 \pm 0.14 \mathrm{Bb}$ & $0.72 \pm 0.06 \mathrm{Bc}$ \\
\hline & i17:0 & dry & $0.59 \pm 0.07 \mathrm{Aa}$ & $0.71 \pm 0.06 \mathrm{Aa}$ & $0.63 \pm 0.05 \mathrm{Aa}$ \\
\hline & & wet & $0.44 \pm 0.01 \mathrm{Ba}$ & $0.52 \pm 0.04 \mathrm{Ba}$ & $0.43 \pm 0.04 \mathrm{Ba}$ \\
\hline & a17:0 & dry & $0.35 \pm 0.05 \mathrm{Aa}$ & $0.53 \pm 0.04 \mathrm{Ab}$ & $0.49 \pm 0.04 \mathrm{Ab}$ \\
\hline & & wet & $0.22 \pm 0.00 \mathrm{Ba}$ & $0.36 \pm 0.03 \mathrm{Bb}$ & $0.30 \pm 0.03 \mathrm{Bb}$ \\
\hline \multirow[t]{6}{*}{ Gram } & $16: 1 w 7 c$ & dry & $0.44 \pm 0.10 \mathrm{Aa}$ & $0.79 \pm 0.09 \mathrm{Ab}$ & $0.72 \pm 0.08 \mathrm{Aab}$ \\
\hline & & wet & $0.22 \pm 0.02 \mathrm{Ba}$ & $0.42 \pm 0.03 \mathrm{Bb}$ & $0.38 \pm 0.04 \mathrm{Bb}$ \\
\hline & су17:0 & dry & $0.22 \pm 0.05 \mathrm{Aa}$ & $0.34 \pm 0.03 \mathrm{Aac}$ & $0.36 \pm 0.05 \mathrm{Abc}$ \\
\hline & & wet & $0.10 \pm 0.01 \mathrm{Ba}$ & $0.21 \pm 0.01 \mathrm{Bb}$ & $0.18 \pm 0.02 \mathrm{Bc}$ \\
\hline & cy19:0 & dry & $1.37 \pm 0.22 \mathrm{Aa}$ & $2.04 \pm 0.21 \mathrm{Ab}$ & $1.60 \pm 0.13 \mathrm{Aab}$ \\
\hline & & wet & $0.82 \pm 0.05 \mathrm{Ba}$ & $1.48 \pm 0.14 \mathrm{Ab}$ & $1.30 \pm 0.10 \mathrm{Ab}$ \\
\hline \multirow[t]{2}{*}{ Saprophytic fungi } & $18: 2 w 6.9 c$ & dry & $0.50 \pm 0.08 \mathrm{Aab}$ & $0.75 \pm 0.04 \mathrm{Aa}$ & $0.48 \pm 0.01 \mathrm{Ab}$ \\
\hline & & wet & $0.30 \pm 0.02 \mathrm{Ba}$ & $0.42 \pm 0.02 \mathrm{Bb}$ & $0.20 \pm 0.02 \mathrm{Bc}$ \\
\hline \multirow[t]{2}{*}{ Ectomycorrhizal fungi } & $18: 1 \omega 9 c$ & dry & $0.90 \pm 0.18 \mathrm{Aa}$ & $1.37 \pm 0.14 \mathrm{Ab}$ & $1.38 \pm 0.09 \mathrm{Ab}$ \\
\hline & & wet & $0.66 \pm 0.05 \mathrm{Aa}$ & $1.09 \pm 0.08 \mathrm{Ab}$ & $0.88 \pm 0.08 \mathrm{Ba}$ \\
\hline \multirow[t]{2}{*}{ Arbuscular mycorrhizal fungi } & $16: 1 \mathrm{w} 5 \mathrm{c}$ & dry & $0.32 \pm 0.07 \mathrm{Aa}$ & $0.50 \pm 0.07 \mathrm{Aab}$ & $0.66 \pm 0.10 \mathrm{Ab}$ \\
\hline & & wet & $0.15 \pm 0.01 \mathrm{Ba}$ & $0.30 \pm 0.03 \mathrm{Bb}$ & $0.43 \pm 0.05 \mathrm{Bc}$ \\
\hline \multirow[t]{2}{*}{$\mathrm{Gram}^{+}$/ Gram } & - & dry & $2.84 \pm 0.07 \mathrm{Aa}$ & $2.44 \pm 0.09 \mathrm{Ab}$ & $2.23 \pm 0.05 \mathrm{Ab}$ \\
\hline & & wet & $3.07 \pm 0.08 \mathrm{Aa}$ & $2.45 \pm 0.11 \mathrm{Ab}$ & $2.06 \pm 0.02 \mathrm{Bc}$ \\
\hline
\end{tabular}


Fig. 5 - Principal component analysis of phospholipid fatty acid

(PLFA) structures in the soils of the three plantations.

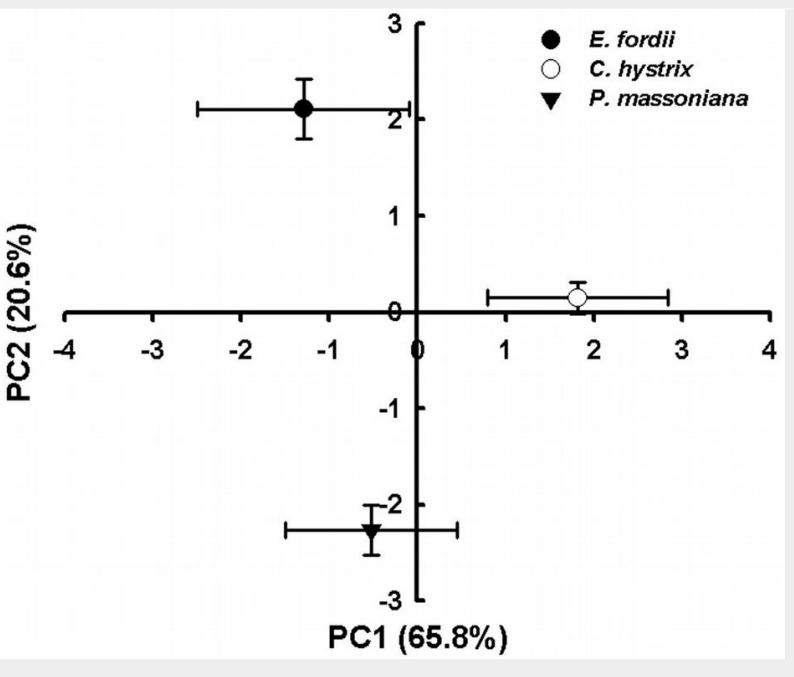

opposite to that of soil MB, total PLFAs, fungal PLFAs and bacterial PLFAs (Tab. 3). While soil respiration and gross nitrification rates were higher during the wet season, soil MB, total PLFAs, fungal PLFAs and bacterial PLFAs reached their lowest values during the same period.

The highest $M B C$ values were in C. hystrix, whereas the highest $M B N$ values were in $E$. fordii for both dry and wet seasons. The $P$. massoniana plantation showed the lowest MBC and MBN contents (Tab. 3). Two

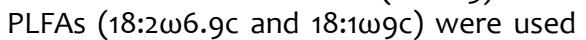
as indicators of fungal biomass. Both PLFAs varied among the plantations. The highest fungal PLFAs were recorded in the $C$. hystrix plantation, followed by $P$. massoniana and E. fordii. Moreover, the highest amount of bacterial PLFAs was in the $C$. hystrix plantation, and the lowest was in the P. massoniana plantation. PLFA-derived $F / B$ ratios did not differ significantly among the plantations (Tab. 3).

\section{Discussion}

Soil respiration and gross nitrification in all the three plantations showed a pronounced seasonal pattern with significantly higher rates during the wet versus the dry season (Fig. 1 and Tab. 3). These findings are consistent with previous reports on the significant seasonal variation of soil respiration and gross nitrification rates in different geographic regions and different tree species (Brüggemann et al. 2005, Kiese et al. 2008, Zhang et al. 2008, Rosenkranz et al. 2010, Lu et al. 2012).

In all the three plantations, soil respiration rate was significantly related to soil temperature and was well described by an exponential function within the temperature range observed in the field (Fig. 2a). This relation has been often described in the literature (Breuer et al. 2002, Rosenkranz et al. 2010, Miao et al. 2010). Regression analysis showed that the observed variance of soil respiration was largely ex- plained by soil temperature $\left(R^{2}=0.76-0.86\right.$; Fig. 2a). These values correspond very well to data of Luan et al. (2011) in a warm-temperate forest ecosystem $\left(R^{2}=0.83-0.93\right)$. Our results also showed that the gross nitrification rate was positively correlated with soil temperature (Fig. 3a). Ingwersen et al. (1999) found the highest gross nitrification at $25{ }^{\circ} \mathrm{C}$, with a $Q_{10}$ value of 4.13 for the temperature range between 15 and 25 ${ }^{\circ} \mathrm{C}$ for coniferous forest in Germany. In the present study, the highest gross nitrification rate was recorded at $27.7^{\circ} \mathrm{C}$, and a $Q_{10}$ value of 5.49 was calculated within the temperature range from 16 to $26^{\circ} \mathrm{C}$. This is somewhat higher than the value obtained by Breuer et al. (2002) for a rainforest ecosystem $\left(Q_{10}=3.60\right.$, temperature range: 14 $24^{\circ} \mathrm{C}$ ) and the values derived from the data set by Ingwersen et al. (1999) for a temperate forest ecosystem. In this context, $Q_{10}$ values derived under field conditions merely indicate the "apparent" temperature sensitivity (Stange \& Neue 2009), because other factors such as WFPS or $\mathrm{N}$ availability are not constant in time and may superimpose with the temperature response. This may explain the quite high $Q_{10}$ values, which are usually not found in lab incubation experiments.

Soil moisture conditions can markedly impact the microbial processes and ecological interactions involved in nutrient cycling, such as soil $\mathrm{C}$ and $\mathrm{N}$ turnover rates (Bengtson et al. 2005, Borken \& Matzner 2009, Chen et al. 2011, Lu et al. 2012). In this study, both soil respiration and gross nitrification rates were positively correlated with soil WFPS (Fig. 2b and Fig. 3b). Some authors reported that soil water content has significant positive effects on soil respiration rates (Miao et al. 2010, Rosenkranz et al. 2010). In addition, Bengtson et al. (2005) and Chen et al. (2011) found that

Tab. 3 - Microbial, fungal and bacterial biomass along with soil respiration and gross nitrification rates of the top soil in the three plantations. Data are means \pm standard error $(n=5)$. A one-way analysis of variance (ANOVA) with a least significant differences (LSD) post-hoc test was used. Different letters indicate significant differences $(P<0.05)$ among plantations (lower case letters) or between different seasons (upper case letters). Soil respiration and gross nitrification rates were normalized to the mean temperature and WFPS.

\begin{tabular}{|c|c|c|c|c|}
\hline Variables & Season & $\begin{array}{l}\text { Erythrophleum } \\
\text { fordii }\end{array}$ & $\begin{array}{c}\text { Castanopsis } \\
\text { hystrix }\end{array}$ & $\begin{array}{c}\text { Pinus } \\
\text { massoniana }\end{array}$ \\
\hline Microbial biomass $\mathrm{C}\left(\mathrm{mg} \mathrm{kg}^{-1}\right)$ & $\begin{array}{l}\text { dry } \\
\text { wet }\end{array}$ & $\begin{array}{l}412.01 \pm 41.98 \mathrm{Aab} \\
205.44 \pm 8.40 \mathrm{Ba}\end{array}$ & $\begin{array}{l}516.01 \pm 29.62 \mathrm{Aa} \\
464.61 \pm 50.90 \mathrm{Ab}\end{array}$ & $\begin{array}{l}368.99 \pm 11.07 \mathrm{Ab} \\
197.36 \pm 6.81 \mathrm{Ba}\end{array}$ \\
\hline Microbial biomass $\mathrm{N}\left(\mathrm{mg} \mathrm{kg}^{-1}\right)$ & $\begin{array}{l}\text { dry } \\
\text { wet }\end{array}$ & $\begin{array}{r}106.66 \pm 8.96 \mathrm{Aa} \\
58.10 \pm 4.69 \mathrm{Ba}\end{array}$ & $\begin{array}{l}89.57 \pm 9.41 \mathrm{Aac} \\
55.82 \pm 2.59 \mathrm{Ba}\end{array}$ & $\begin{array}{l}69.40 \pm 7.76 \mathrm{Abc} \\
53.67 \pm 3.79 \mathrm{Aa}\end{array}$ \\
\hline Microbial $\mathrm{C}: \mathrm{N}$ ratio & $\begin{array}{l}\text { dry } \\
\text { wet }\end{array}$ & $\begin{array}{l}3.87 \pm 0.26 \mathrm{Aa} \\
3.60 \pm 0.24 \mathrm{Aa}\end{array}$ & $\begin{array}{l}6.11 \pm 0.94 \mathrm{Aa} \\
8.48 \pm 1.11 \mathrm{Ab}\end{array}$ & $\begin{array}{l}5.71 \pm 0.88 \mathrm{Aa} \\
3.79 \pm 0.37 \mathrm{Aa}\end{array}$ \\
\hline Total PLFAs $\left(\mathrm{nmol} \mathrm{g}^{-1}\right)$ & $\begin{array}{l}\text { dry } \\
\text { wet }\end{array}$ & $\begin{array}{l}18.46 \pm 2.23 \mathrm{Aa} \\
10.65 \pm 0.20 \mathrm{Ba}\end{array}$ & $\begin{array}{l}20.89 \pm 1.64 \mathrm{Aa} \\
14.42 \pm 0.92 \mathrm{Bb}\end{array}$ & $\begin{array}{r}16.19 \pm 0.42 \mathrm{Aa} \\
9.73 \pm 0.44 \mathrm{Ba}\end{array}$ \\
\hline Fungi (nmol g-1) & $\begin{array}{l}\text { dry } \\
\text { wet }\end{array}$ & $\begin{array}{l}1.41 \pm 0.25 \mathrm{Aa} \\
0.97 \pm 0.07 \mathrm{Aa}\end{array}$ & $\begin{array}{l}2.12 \pm 0.18 \mathrm{Ab} \\
1.52 \pm 0.09 \mathrm{Bb}\end{array}$ & $\begin{array}{l}1.86 \pm 0.09 \mathrm{Aab} \\
1.07 \pm 0.10 \mathrm{Ba}\end{array}$ \\
\hline Bacteria $\left(\mathrm{nmol} \mathrm{g}^{-1}\right)$ & $\begin{array}{l}\text { dry } \\
\text { wet }\end{array}$ & $\begin{aligned} 12.16 & \pm 1.43 \mathrm{Aa} \\
6.48 & \pm 0.18 \mathrm{Ba}\end{aligned}$ & $\begin{array}{r}14.67 \pm 1.17 \mathrm{Aa} \\
9.59 \pm 0.67 \mathrm{Bb}\end{array}$ & $\begin{array}{r}11.84 \pm 1.05 \mathrm{Aa} \\
6.29 \pm 0.32 \mathrm{Ba}\end{array}$ \\
\hline $\mathrm{F}: \mathrm{B}$ ratio & $\begin{array}{l}\text { dry } \\
\text { wet }\end{array}$ & $\begin{array}{l}0.12 \pm 0.02 \mathrm{Aa} \\
0.15 \pm 0.01 \mathrm{Aa}\end{array}$ & $\begin{array}{l}0.15 \pm 0.01 \mathrm{Aa} \\
0.16 \pm 0.01 \mathrm{Aa}\end{array}$ & $\begin{array}{l}0.16 \pm 0.01 \mathrm{Aa} \\
0.17 \pm 0.02 \mathrm{Aa}\end{array}$ \\
\hline Soil respiration $\left(\mathrm{mg} \mathrm{C} \mathrm{kg}^{-1} \mathrm{sdw} \mathrm{d}^{-1}\right)$ & $\begin{array}{l}\text { dry } \\
\text { wet }\end{array}$ & $\begin{aligned} 4.80 & \pm 1.67 \mathrm{Aa} \\
25.26 & \pm 1.72 \mathrm{Ba}\end{aligned}$ & $\begin{array}{r}6.76 \pm 1.11 \mathrm{Aa} \\
20.96 \pm 1.13 \mathrm{Ba}\end{array}$ & $\begin{array}{r}6.21 \pm 0.46 \mathrm{Aa} \\
22.04 \pm 1.97 \mathrm{Ba}\end{array}$ \\
\hline Gross nitrification (mg N kg${ }^{-1} \mathrm{sdw} \mathrm{d}^{-1}$ ) & $\begin{array}{l}\text { dry } \\
\text { wet }\end{array}$ & $\begin{array}{l}0.13 \pm 0.05 \mathrm{Aa} \\
1.45 \pm 0.10 \mathrm{Ba}\end{array}$ & $\begin{array}{l}0.11 \pm 0.02 \mathrm{Aa} \\
0.77 \pm 0.11 \mathrm{Bb}\end{array}$ & $\begin{array}{l}0.11 \pm 0.03 \mathrm{Aa} \\
1.36 \pm 0.19 \mathrm{Ba}\end{array}$ \\
\hline
\end{tabular}


both respiration and gross nitrification rates in forest ecosystems increase with increasing moisture under field conditions. Our study demonstrates that those results are applicable under field conditions in subtropical plantations.

Soil $\mathrm{C}$ and $\mathrm{N}$ turnover are controlled by microbial processes. In general, a warm and humid season is expected to be more favorable for mineralization, whereas the dry season is typically more favorable for immobilization. We found lowest $M B C$, $M B N$, total PLFAs, fungal PLFAs and bacterial PLFAs during the wet season, when temperature and soil moisture conditions were favorable for the microbial community (Tab. 3). During the period of the lowest $M B$, however, we observed the highest soil respiration and gross nitrification rates (Tab. 3). This finding agrees very well with the results of Maithani et al. (1996) and Arunachalam et al. (1998). They found that, in regrowth of a disturbed subtropical humid forest in north-east India, the periods of high mineralization coincided with minimum MB, whereas periods of immobilization corresponded with times of highest MB. In the subtropical forest of Meghalaya, India, Das et al. (1997) also reported highest $\mathrm{N}$-mineralization rates in the rainy season, while MBN was low in the rainy season and high in the dry winter season. As discussed by Maithani et al. (1996) and Barbhuiya et al. (2004), lower MB values during the rainy season, when temperature and soil moisture conditions were favorable for the microbes, indicated a period of rapid mineralization in soil. Sarathchandra et al. (1984) and Singh et al. (1991) reported that the relatively greater nutrient demand by plants during the wet season (the peak vegetative growth period) limited the availability of nutrients to soil microbes and thereby reduced their immobilization in MB. Moreover, when soil dries out during the dry season, substrate supply might become limiting. Then, microbes may experience resource limitation that can slow down biogeochemical processes and force microbes into a dormant state (Stark \& Firestone 1995, Schimel et al. 2007). During the dry season, low water content can inhibit microbial activity by lowering intracellular water potential. This causes microbes to acclimate to decreasing water potentials by altering their allocation of resources (Schimel et al. 2007). We therefore expect that microorganisms use most of the available resources to synthesize biomass during the transition between wet and dry season. Chen et al. (2003) also found that a high level of MBC and MBN in late winter in a hoop pine plantation coincided with low temperatures and low microbial activity.

Soil MB and microbial community composition have been shown to affect soil $C$ and $\mathrm{N}$ cycling (Boyle et al. 2008, Yin et al. 2012, Lu et al. 2012). Soil in the $E$. fordii plantation had higher concentrations of SOC, TN, inorganic $\mathrm{N}$ and $\mathrm{MBN}$ than soil in the two other plantations (Tab. 1 and Tab. 3). Moreover, the highest $\mathrm{C}$ and $\mathrm{N}$ turnover rates coincided with the lowest fungal biomass and highest $\mathrm{N}$ availability (Tab. 1 and Tab. 3). This agrees with other studies that found fungal biomass to be negatively correlated with soil fertility and $\mathrm{N}$ availability (Grayston \& Prescott 2005, Högberg et al. 2007, Boyle et al. 2008). This may be caused by microbial communities affecting $\mathrm{C}$ and $\mathrm{N}$ processes or, more likely, by $\mathrm{N}$ availability affecting the microbial communities (Grayston \& Prescott 2005).

\section{Conclusions}

The present study revealed no significant differences in soil respiration and gross nitrification among the three plantations, but seasonal variation in the $\mathrm{C}$ and $\mathrm{N}$ processes was highly significant. The seasonal variation of soil respiration and gross nitrification was mostly controlled by environmental factors such as soil temperature and soil water content. The role of the microbial community in this context was less clear, while respiration and nitrification were related to MBN and fungal biomass. Moreover, MB and total PLFA content were negatively correlated with $\mathrm{C}$ and $\mathrm{N}$ turnover, showing that these two measures alone are poor indicators for microbial activity in soils that experience environmental stress such as drought.

\section{Abbreviations}

The following abbreviations were used throughout the paper:

- BaPS: barometric process separation;

- PLFA: phospholipid fatty acid;

- MB: microbial biomass;

- SOC: soil organic carbon;

- TN: total nitrogen;

- MBC: microbial biomass carbon;

- MBN: microbial biomass nitrogen;

- $\mathrm{T}_{5}$ : soil temperature at $5 \mathrm{~cm}$ soil depth;

- F/B: ratio of fungal to bacterial biomass;

- RQ: respiration quotient;

- WFPS: water-filled pore space;

- $\mathrm{Q}_{10}$ : temperature sensitivity;

- SDW: soil dry weight.

\section{Acknowledgements}

We are grateful to Lihua Lu, Haolong Yu and Angang Ming for their help with field sampling. This study was funded by the Project in the National Science \& Technology Pillar Program during the Twelfth Fiveyear Plan Period (No. 2012BAD22B0102), National Scientific Foundation of China (31290223) and the Project of the Special Program on Carbon of the Chinese Academy of Sciences (No. XDA05060100).

\section{References}

Arunachalam A, Maithani K, Pandey HN, Tripathi RS (1998). Leaf litter decomposition and nutrient mineralization patterns in regrowing stands of a humid subtropical forest after tree cutting. Forest Ecology and Management 109: 151-161. - doi: 10.1016/S0378-1127(98)00240-0

Bååth E, Anderson TH (2003). Comparison of soil fungal/bacterial ratios in a $\mathrm{pH}$ gradient using physiological and PLFA-based techniques. Soil Biology and Biochemistry 35: 955-963. - doi: 10.1016/S0038-0717(03)00154-8

Barbhuiya AR, Arunachalam A, Pandey HN, Arunachalam K, Khan ML, Nath PC (2004). Dynamics of soil microbial biomass $C, N$ and $P$ in disturbed and undisturbed stands of a tropical wet-evergreen forest. European Journal of Soil Biology 40: 113-121. - doi: 10.1016/j.ejsobi.2005. 02.003

Bardgett RD, Hobbs PJ (1996). Changes in soil fungal: bacterial biomass ratios following reductions in the intensity of management of an upland grassland. Biology and Fertility of Soils 22: 261-264. - doi: 10.1007/BF00382522

Bauhus J, Paré D, Coté L (1998). Effects of tree species, stand age and soil type on soil microbial biomass and its activity in a southern boreal forest. Soil Biology and Biochemistry 30: 1077-1089. - doi: 10.1016/So038-0717(97)00213-7 Bengtson P, Falkengren-Grerup U, Bengtsson G (2005). Relieving substrate limitation-soil moisture and temperature determine gross $\mathrm{N}$ transformation rates. Oikos 111: 81-90. - doi: 10.1111/j. 0030-1299.2005.13800.x

Binkley D, Giardina C (1998). Why do tree species affect soils? The warp and woof of tree-soil interactions. Biogeochemistry 42: 89-106. - doi: 10.1023/A:1005948126251

Borken W, Matzner E (2009). Reappraisal of drying and wetting effects on $\mathrm{C}$ and $\mathrm{N}$ mineralization and fluxes in soils. Global Change Biology 15: 808-824. - doi: 10.1111/j.1365-2486.2008.016 81. $\mathrm{x}$

Boyle SA, Yarwood RR, Bottomley PJ, Myrold DD (2008). Bacterial and fungal contributions to soil nitrogen cycling under Douglas fir and red alder at two sites in Oregon. Soil Biology and Biochemistry 40: 443-451. - doi: 10.1016/j.soilbio. 2007.09.007

Bossio DM, Scow KM (1998). Impacts of carbon and flooding on soil microbial communities: phospolipid fatty acid profiles and substrate utilization patterns. Microbial Ecology 35: 265 278. - doi: 10.1007/s002489900082

Breuer L, Kiese R, Butterbach-Bahl K (2002). Temperature and moisture effects on nitrification rates in tropical rain-forest soils. Soil Science Society of America Journal 66: 834-844. doi: $10.2136 /$ sssaj2002.8340

Brüggemann N, Rosenkranz P, Papen H, Pilegaard K, Butterbach-Bahl K (2005). Pure stands of temperate forest tree species modify soil respiration and $\mathrm{N}$ turnover. Biogeosciences Discussions 2: 303-331. - doi: 10.5194/bgd-2-303-20 05

Burton J, Chen CR, Xu ZH, Ghadiri H (2007). Gross nitrogen transformations in adjacent native and plantation forests of subtropical Australia. Soil Biology and Biochemistry 39: 426-433. - doi: 10.1016/j.soilbio.2006.08.011

Chen CR, Xu ZH, Blumfield TJ, Hughes JM (2003). Soil microbial biomass during the early establishment of hoop pine plantation: seasonal variation and impacts of site preparation. Forest Ecology and Management 186: 213-225. - doi: 10.1016/S0378-1127(03)00275-5

Chen YT, Borken W, Stange CF, Matzner E (2011). Effects of decreasing water potential on gross ammonification and nitrification in an acid 
coniferous forest soil. Soil Biology and Biochemistry 43: 333-338. - doi: 10.1016/j.soilbio. 2010.10.020

Das AK, Boral L, Tripathi RS, Pandey HN (1997). Nitrogen mineralisation and microbial biomass$\mathrm{N}$ in a subtropical humid forest of Meghalaya, India. Soil Biology and Biochemistry 29: 16091612. - doi: 10.1016/S0038-0717(96)00298-2 Grayston SJ, Prescott CE (2005). Microbial communities in forest floors under four tree species in coastal British Columbia. Soil Biology and Biochemistry 37: 1157-1167. - doi: 10.1016/j.soil bio.2004.11.014

Grenon F, Bradley RL, Titus BD (2004). Temperature sensitivity of mineral $\mathrm{N}$ transformation rates, and heterotrophic nitrification: possible factors controlling the post-disturbance mineral $\mathrm{N}$ flush in forest floors. Soil Biology and Biochemistry 36: 1465-1474. - doi: 10.1016/j.soil bio.2004.04.021

Hackl E, Pfeffer M, Donat C, Bachmann G, Zechmeister-Boltenstern S (2005). Composition of the microbial communities in the mineral soil under different types of natural forest. Soil Biology and Biochemistry 37: 661-671. - doi: 10.1016/ j.soilbio.2004.08.023

Högberg MN, Högberg P, Myrold DD (2007). Is microbial community composition in boreal forest soils determined by $\mathrm{pH}, \mathrm{C}$-to- $\mathrm{N}$ ratio, the trees, or all three? Oecologia 150: 590-601. - doi: 10.1007/s00442-006-0562-5

Huang XM, Liu SR, Wang H, Hu ZD, Li ZG, You YM (2014). Changes of soil microbial biomass carbon and community composition through mixing nitrogen-fixing species with Eucalyptus urophylla in subtropical China. Soil Biology and Biochemistry 73: 42-48. - doi: 10.1016/j.soilbio.2014. 01.021

Ingwersen J, Butterbach-Bahl K, Gasche R, Richter O, Papen H (1999). Barometric process separation: new method for quantifying nitrification, denitrification, and nitrous oxide sources in soils. Soil Science Society of America Journal 63: 117-128. - doi: 10.2136/sssaj1999.0361599500 6300010018x

Ingwersen J, Schwarz U, Stange CF, Ju XT, Streck T (2008). Shortcomings in the commercialized barometric process separation measuring system. Soil Science Society of America Journal 72: 135-142. - doi: 10.2136/sssaj2007.00 92

Janssens IA, Lankreijer H, Matteucci G, Kowalski AS, Buchmann N, Epron D, Pilegaard K, Kutsch W, Longdoz B, Grunwald T, Montagnani L, Dore S, Rebmann C, Moors EJ, Grelle A, Rannik U, Morgenstern K, Oltchev S, Clement R, Gudmundsson J, Minerbi S, Berbigier P, Ibrom A, Moncrieff J, Aubinet $M$, Bernhofer $C$, Jensen NO, Vesala T, Granier A, Schulze ED, Lindroth A, Dolman AJ, Jarvis PG, Ceulemans R, Valentini R (2001). Productivity overshadows temperature in determining soil and ecosystem respiration across European forests. Global Change Biology 7: 269-278. - doi: 10.1046/j.1365-2486.2001. 00412.x

Kiese R, Hewett B, Butterbach-Bahl K (2008). Seasonal dynamic of gross nitrification and $\mathrm{N}_{2} \mathrm{O}$ emission at two tropical rainforest sites in Queensland, Australia. Plant and Soil 309: 105117. - doi: 10.1007/s11104-007-9468-1

Kiese R, Papen H, Zumbusch E, Butterbach-Bahl
K (2002). Nitrification activity in tropical rain forest soils of the Coastal Lowlands and Atherton Tablelands, Queensland, Australia. Journal of Plant Nutrition and Soil Science 165: 682-685. doi: 10.1002/jpln.200290003

Liang RL, Wen HH (1992). Application of fertilizers in Pinus massoniana plantations in Daqingshan, Guangxi Province. Forest Research 5: 138142. [online] URL: http://en.cnki.com.cn/Article en/CJFDTOTAL-LYKX199201023.htm

Liu GS, Jiang NH, Zhang LD, Liu ZL (1996). Soil physical and chemical analysis and description of soil profiles. Standards Press of China, Beijing, China, pp. 31-32. [in Chinese]

Lu XY, Yan Y, Fan JH, Wang XD (2012). Gross nitrification and denitrification in Alpine Grassland Ecosystems on the Tibetan Plateau. Arctic, Antarctic, and Alpine Research 44: 188-196. - doi: 10.1657/1938-4246-44.2.188

Luan JW (2010). Temporal and spatial variations of soil respiration and its controlling factors in warm-temperate Oak (Quercus acutidentata) forests. Dissertation for the Degree, Chinese Academy of Forestry, Beijing, China, pp. 62. [in Chinese]

Luan JW, Liu SR, Wang JX, Zhu XL, Shi ZM (2011). Rhizospheric and heterotrophic respiration of a warm-temperate oak chronosequence in China. Soil Biology and Biochemistry 43: 503-512. - doi: 10.1016/j.soilbio.2010.11.010

Luan JW, Liu SR, Zhu XL, Wang JX, Liu K (2012). Roles of biotic and abiotic variables in determining spatial variation of soil respiration in secondary oak and planted pine forests. Soil Biology and Biochemistry 44: 143-150. - doi: 10.1016/j.soilbio.2011.08.012

Maithani K, Tripathi RS, Arunachalam A, Pandey HN (1996). Seasonal dynamics of microbial biomass $\mathrm{C}, \mathrm{N}$ and $\mathrm{P}$ during regrowth of a disturbed subtropical humid forest in north-east India. Applied Soil Ecology 4: 31-37. - doi: 10.1016/0929-1393(96)00101-1

Matejek B, Huber C, Dannenmann M, Kohlpaintner M, Gasche R, Göttlein A, Papen H (2010). Microbial nitrogen-turnover processes within the soil profile of a nitrogen-saturated spruce forest and their relation to the small-scale pattern of seepage-water nitrate. Journal of Plant Nutrition and Soil Science 173: 224-236. - doi: 10.1002/jpln.200800226

Matejek B, Kohlpaintner M, Gasche R, Huber C, Dannenmann M, Papen H (2008). The smallscale pattern of seepage water nitrate concentration in an $\mathrm{N}$ saturated spruce forest is regulated by net $\mathrm{N}$ mineralization in the organic layer. Plant and Soil 310: 167-179. - doi: 10.1007/ s11104-008-9643-z

Miao FQ, Wang JS, Sun JC, Kang FF, Zhao XH, He ZS (2010). Conversion rate of soil carbon and nitrogen in natural Pinus tabulaeformis forest on the Taiyue Mountains, China. Chinese Journal of Applied and Environmental Biology 16: 519-522. [online] URL: http://en.cnki.com.cn/Ar ticle en/CJFDTOTAL-YYHS201004018.htm

Müllèr C, Abbasi MK, Kammann C, Clough TJ, Sherlock RR, Stevens RJ, Jäger HJ (2004). Soil respiratory quotient determined via barometric process separation combined with nitrogen-15 labeling. Soil Science Society of America Journal 68: 1610-1615. - doi: 10.2136/sssaj2004.1610

Munson AD, Timmer VR (1995). Soil nitrogen dynamics and nutrition of pine following silvicultural treatments in boreal and Great LakesSt. Lawrence plantations. Forest Ecology and Management 76: 169-179. - doi: 10.1016/03781127(95)03547-N

Neill C, Piccolo MC, Melillo JM, Steudler PA, Cerri CC (1999). Nitrogen dynamics in Amazon forest and pasture soils measured by ${ }^{15} \mathrm{~N}$ pool dilution. Soil Biology and Biochemistry 31: 567-572. - doi: 10.1016/S0038-0717(98)00159-X

Paavolainen L, Smolander A (1998). Nitrification and denitrification in soil from a clear-cut Norway spruce (Picea abies) stand. Soil Biology and Biochemistry 30: 775-781. - doi: 10.1016/S00380717(97)00165-X

Palmroth S, Maier CA, McCarthy HR, Oishi AC, Kim HS, Johnsen KH, Katul GG, Oren R (2005). Contrasting responses to drought of forest floor $\mathrm{CO}_{2}$ efflux in a loblolly pine plantation and a nearby Oak-Hickory forest. Global Change Biology 11: 421-434. - doi: 10.1111/j.1365-2486. 2005.00915.x

Patra AK, Abbadie L, Clays-Josserand A, Degrange V, Grayston SJ, Guillaumaud N, Loiseau P, Louault F, Mahmood S, Nazaret S, Phillippot L, Poly F, Prosser JI, Le Roux X (2006). Effects of management regime and plant species on the enzyme activity and genetic structure of $\mathrm{N}$ fixing, denitrifying and nitrifying bacterial communities in grassland soils. Environmental Microbiology 8: 1005-1016. - doi: 10.1111/j.1462-29 20.2006.00992.x

Rosenkranz P, Brüggemann N, Papen $H, X u Z$, Horváth L, Butterbach-Bahl K (2006). Soil N and $\mathrm{C}$ trace gas fluxes and microbial soil $\mathrm{N}$ turnover in a sessile oak (Quercus petraea (Matt.) Liebl.) forest in Hungary. Plant and Soil 286: 301-322. doi: 10.1007/s11104-006-9045-z

Rosenkranz P, Dannenmann M, Brüggemann N, Papen H, Berger U, Zumbusch E, ButterbachBahl K (2010). Gross rates of ammonification and nitrification at a nitrogen-saturated spruce (Picea abies (L.) Karst.) stand in southern Germany. European Journal of Soil Science 61: 745758. - doi: 10.1111/j.1365-2389.2010.01274.x

Ryan MG, Law BE (2005). Interpreting, measuring, and modeling soil respiration. Biogeochemistry 73: 3-27. - doi: 10.1007/s10533-004-5167-7 Sarathchandra SU, Perrott KW, Upsdell MP (1984). Microbiological and biochemical characteristics of a range of New Zealand soils under established pasture. Soil Biology and Biochemistry 16: 177-183. - doi: 10.1016/0038-0717(84)90 109-3

Schimel J, Balser TC, Wallenstein M (2007). Microbial stress-response physiology and its implications for ecosystem function. Ecology 88: 1386-1394. - doi: 10.1890/06-0219

Singh RS, Srivastava SC, Raghubanshi AS, Singh JS, Singh SP (1991). Microbial C, N and P in dry tropical savanna: effects of burning and grazing. Journal of Applied Ecology 28: 869-878. doi: $10.2307 / 2404213$

Staelens J, Rütting T, Huygens D, Schrijver AD, Müller C, Verheyen K, Boeckx P (2012). In situ gross nitrogen transformations differ between temperate deciduous and coniferous forest soils. Biogeochemistry 108: 259-277. - doi: 10.1007/s10533-011-9598-7

Stange CF, Neue H-U (2009). Measuring and modelling seasonal variation of gross nitrifica- 
tion rates in response to long-term fertilisation. Biogeosciences 6: 2181-2192. - doi: 10.5194/bg-62181-2009

Stark JM, Firestone MK (1995). Mechanisms for soil moisture effects on activity of nitrifying bacteria. Applied and Environmental Microbiology 61: 218-221. [online] URL: http://aem.asm. org/content/61/1/218.short

Stark JM, Hart SC (1997). High rates of nitrification and nitrate turnover in undisturbed coniferous forests. Nature 385: 61-64. - doi: 10.1038/ $385061 a 0$

Ste-Marie C, Houle D (2006). Forest floor gross and net nitrogen mineralization in three forest types in Quebec, Canada. Soil Biology and Biochemistry 38: 2135-2143. - doi: 10.1016/j.soilbio. 2006.01.017

Tate KR, Ross DJ, Feltham CW (1988). A direct extraction method to estimate soil microbial C: effects of experimental variables and some different calibration procedures. Soil Biology and Biochemistry 20: 329-335. - doi: 10.1016/00380717(88)90013-2

Templer P, Findlay S, Lovett G (2003). Soil microbial biomass and nitrogen transformations among five tree species of the Catskill Moun- tains, New York, USA. Soil Biology and Biochemistry 35: 607-613. - doi: 10.1016/S0038-0717 (03)00006-3

Torbert HA, Wood CW (1992). Effects of soil compaction and water-filled pore space on soil microbial activity and $\mathrm{N}$ losses. Communications in Soil Science and Plant Analysis 23: 13211331. - doi: 10.1080/00103629209368668

Tunlid A, Hoitink HAJ, Low C, White DC (1989). Characterization of bacteria that suppress rhizoctonia damping-off in bark compost media by analysis of fatty acid biomarkers. Applied and Environmental Microbiology 55: 1368-1374. [online] URL: http://aem.asm.org/content/55/6/ 1368.short

Vance ED, Brookes PC, Jenkinson DS (1987). An extraction method for measuring soil microbial biomass C. Soil Biology and Biochemistry 19: 703-707. - doi: 10.1016/0038-0717(87)90052-6

Wang FM, Li ZA, Xia HP, Zou B, Li NY, Liu J, Zhu $W X$ (2010a). Effects of nitrogen-fixing and nonnitrogen-fixing tree species on soil properties and nitrogen transformation during forest restoration in southern China. Soil Science and Plant Nutrition 56: 297-306. - doi: 10.1111/j.17470765.2010.00454.x
Wang H, Liu SR, Mo JM, Wang JX, Makeschin F, Wolff M (2010b). Soil organic carbon stock and chemical composition in four plantations of indigenous tree species in subtropical China. Ecological Research 25: 1071-1079. - doi: 10.1007/ s11284-010-0730-2

Wang WX, Shi ZM, Luo D, Liu SR, Lu LH, Ming AG, Yu HL (2013). Carbon and nitrogen storage under different plantations in subtropical south China. Acta Ecologica Sinica 3: 925-933. [in Chinese] - doi: 10.5846/stxb201207040935 Westbrook CJ, Devito KJ, Allan CJ (2006). Soil N cycling in harvested and pristine boreal forests and peatlands. Forest Ecology and Management 234: 227-237. - doi: 10.1016/j.foreco.2006. 07.004

Yin HJ, Chen Z, Liu Q (2012). Effects of experimental warming on soil $\mathrm{N}$ transformations of two coniferous species, Eastern Tibetan Plateau, China. Soil Biology and Biochemistry 50: 77-84. - doi: 10.1016/j.soilbio.2012.03.004

Zhang XL, Wang QB, Li LH, Han XG (2008). Seasonal variations in nitrogen mineralization under three land use types in a grassland landscape. Acta Oecologica 34: 322-330. - doi: 10.1016/j.actao.2008.06.004 